\title{
Effect of Smilax China L. Extract on Cultured NIH3T3 Fibroblasts Damaged by Mercury as Allergic Contact Dermatitis Inducer
}

\author{
Sun-Hee Han $^{1}$ and Seung-Joo Jekal ${ }^{2}$ \\ Departments of ${ }^{1}$ Nursing, ${ }^{2}$ Clinical Laboratory Science, Wonkwang Health Science University, Iksan 54538, Korea
}

\section{알러지성 접촉피부염 유발제인 수은으로 손상된 배양 NIH3T3 섬유모세포에 대한 청미래덩굴 추출물의 효과}

한선희 ${ }^{1}$, 제갈승주 ${ }^{2}$

원광보건대학교 ${ }^{1}$ 간호학과, ${ }^{2}$ 임상병리학과

\begin{abstract}
In order to examine the effect of Smilax china L. (SC) extract on the cytotoxicity of methymercuric chloride (MMC), allergic contact dermatitis, The cytotoxicity of MMC was assessed after cultured NIH3T3 fibroblasts were treated with various concentrations of MMC for 72 hours. And also, the following results were obtained by measuring the antioxidative effect of SC extract on the cytotoxicity of MMC. In this study, MMC remarkably decreased the cell viability of NIH3T3 fibroblasts in a dose-dependent manner, and MMC was seen to be highly-toxic below $100 \mathrm{uM}$ of XTT50 value. In addition, the toxicity of MMC was involved in oxidative stress via a blockage of MMC-induced cytotoxicity by vit. E as antioxidant. In the protective effect of SC extract on MMC-induced cytotoxicity, SC extract defended the cytotoxicity of MMC by a significant increase of cell viability which was decreased by MMC-induced cytotoxicity. It also showed antioxidative effects such as electron donating ability (EDA), superoxide dismutase (SOD)-like activity (SLA) and the lipid peroxidation activity (LPA). From these results, the natural component as SC extract may be a putative resource as the antioxidative agent for the treatment of inflammatory skin disease associated with the oxidative stress.
\end{abstract}

Keywords: Allergic contact dermatitis, Antioxidative effect, Inflammatory skin disease

This is an Open Access article distributed under the terms of the Creative Commons Attribution Non-Commercial License (http://creativecommons.org/licenses/by-nc/4.0) which permits unrestricted non-commercial use, distribution, and reproduction in any medium, provided the original work is properly cited.

Copyright (c) 2015 The Korean Society for Clinical Laboratory Science. All rights reserved.
Corresponding author: Seung-Joo Jekal Department of Clinical Laboratory Science, Wonkwang Health Science University, Iksan 54538, Korea

Tel: 82-63-840-1210

E-mail: sjjei@wu.ac.kr

Received: November 1, 2015

Revised $1^{\text {st: }}$ November 17, 2015

Revised $2^{\text {nd: }}$ : November 25, 2015

Accepted: November 26, 2015
서 론

수은은 돌연변이원인인 동시에 알레르기성 접촉피부염 유발제 로 알려져 있으나 일상생활에 필요한 온도계를 비롯하여 수은전지, 치아 아말감 및 자동차부품과 같은 산업부문에 주된 원료로 사용되 고 있으며, 미백이나 살균을 목적으로 화장품부문에서도 승홍 $\left(\mathrm{HgCl}_{2}\right)$ 이란 이름으로 널리 사용되어 왔다(Son 등, 2013). 수은화
합물은 승홍이나 뇌홍과 같은 무기수은화합물과 페닐수은이나 알 킬수은 및 메틸수은과 같은 유기수은화합물로 나뉘는데 유기수은 화합물은 무기수은화합물 보다 독성이 횔씬 강하기 때문에 취급 시 특별한 주의를 요한다(Greener와 Kochen, 1983). 1953년 일본의 미나마타만의 수은중독이나 1972년 이라크의 알킬수은농약 오염 에 의한 중독의 사건을 계기로 독성이 강한 수은중독에 의한 부작 용은 관심의 대상이 되었다(Tsubaki와 Takahashi, 1986). 그럼에 
도 불구하고 아직까지 이의 중독현상에 대한 자세한 기전은 물론, 효과적인 치료방법이나 치료약제가 매우 부족한 실정이다(Kim 등, 2010). 수은에 대한 한 연구에서 수은을 포함한 크롬이나 구리 와같은 몇몇 중금속류는 이들의 붕괴 시 자유라디칼을 생성한다는 것이 제시되면서 수은독성이 산화적 손상과 관련이 있다는 것이 보 고된 바 있다(Gage, 1975). 실제로 수은으로 손상된 배양 세포에 항산화제를 투여한 결과 수은의 독성이 경감되었다고 보고된 바 있 다(Park 등, 1996). 현재, 수은중독에 대한 기전을 산화적 손상 (oxidative stress) 측면에서 접근하는 연구가 진행되고 있다. 자유 라디칼에 의한 산화적 손상은 세포내 항산화 효소의 활성저해를 비 롯한 세포내 칼슘과 연관된 N-methyl-D-aspartate 수용체의 활 성, 흥분성 아미노산(excitatory amino acids, EAAs)의 분비와 같 은 현상을 초래하여 세포를 퇴화 내지는 고사(apoptosis)시킨다고 알려져 있다(Park 등, 1996).

최근, 허브를 비롯한 한약제나 약용식물 중에는 항산화를 비롯 한 항암, 항염, 항독 등에 유효한 성분들을 다량 포함하고 있다는 것 이 밝혀지면서 이들 성분에 대한 생리활성을 규명하려는 연구가 진 행되고 있다(Li 등, 2007; Rim 등, 2010). 그 결과 페놀화합물 (phenolic compound)을 비롯한 이소프레노이드(isoprenoid) 및 배당체(glycoside)와 같은 물질들이 항균이나 항독, 항산화와 같은 유효한 활성을 나타낸다고 보고되었다(De-Heredia 등, 2001; Kwon, 2015).

식물 중 청미래덩굴(Smilax china L., SC)은 우리나라 전국에 서 식하고 있는 낙엽활엽수로서 백합과(Liliaceae)에 속하는 다년생 덩굴성 식물이다. 청미래덩굴의 꽃은 5월경에 개화하는데 9 10 월경에는 붉은색의 열매를 맺는다(Li 등, 2007). 생약명은 토복령 또는 우계라고도 부르며, 주로 뿌리나 줄기를 약제로 많이 사용하 여 왔으며, 관절염, 임파선염, 독중독과 같은 질환에 유효한 효과가 있다(Pyo 등, 2013). 특히 청미래덩굴의 잎은 발계엽이라 하여 중 금속 독성에 대한 예방에 효과가 있으며, 줄기와 열매도 피부질환 과 같은 병변에도 효과가 있어 전초 모두가 약제로서 사용 가능하 다(Oh, 2011). 청미래덩굴에는 사포닌(saponin)을 비롯한 스밀라 신(smilacin), 파릴린(parillin), 리놀레산(linoleic acid) 및 올레인 산(oleic acid)과 같은 다양한 성분들이 함유되어 있으며, 이들 성 분 중 사포닌이나 리놀레산 및 올레인산은 항산화 작용이 뛰어난 것으로 알려져 있다(Chang, 2003).

최근, 세포 배양법이 발달함에 따라 배양 세포를 이용하여 각종 질환의 병인적 기전규명을 비롯하여 신물질의 효능이나 또는 독성 물질의 독성정도를 측정하는 도구로 자리잡고 있다. 세포 배양은 동질의 재료를 쉽게 다량 확보할 수 있으며, 동일한 실험을 여러번 반복할 수 있어 재현성이 뛰어나다는 장점을 가지고 있다(Song 등,
2002).

따라서 본 연구는 알러지성 접촉피부염(allergic contact dermatitis)과 같은 염증성 피부질환에 치료적 효과를 가지고 있는 천연소재의 탐색 일환으로, 청미래덩굴 추출물을 재료로 배양 $\mathrm{NIH3T3}$ 섬유모세포에 알러지성 접촉피부염 유발제인 메틸수은 (methymercuric chloride, MMC)을 처리한 후 추출물의 영향을 항산화 측면에서 조사하였다.

\section{재료 및 방법}

\section{1. 실험재료}

NIH3T3 섬유모세포는 American Type Culture Collection (ATCC)에서 분양 받아 사용하였다.

\section{2. 약제 제조}

본 실험에 사용한 시약으로는 methymercuric chloride $(\mathrm{MMC})$ 를 비롯한 vitamin E (vit. E), 1,1-diphenyl-2-picrylhydrazyl (DPPH), ethanol, pyrogallol, ammonium thiocyanate, phosphate buffered saline (PBS), fetal bovine serum (FBS), minimum essential medium (MEM), 哭 XTT (2,3-bis-[2-methoxy-4-nitro-5-sulfophenyl]-2H-tetrazolium-5-caboxanilide, disodium salt)는 Sigma사(Sigma Chemical Company, St. Louis, $\mathrm{MO}, \mathrm{USA}$ )에서 각각 구입하였다. MMC의 제조는 $\mathrm{FBS}$ 가 없 는 배양액을 사용하여 최종 농도가 각각 $20 \mathrm{uM}, 50 \mathrm{uM}, 80 \mathrm{uM}$ 및 $100 \mathrm{uM}$ 의 저장액을 만들어 냉암소에 보관한 후 실험 직전 필요한 양을 배양액에 직접 첨가하여 사용하거나 또는 필요농도로 희석하 여 사용하였다. XTT는 실험 전날 $\mathrm{PBS}$ 를 이용하여 $50 \mathrm{ug} / \mathrm{mL}$ 의 저 장액을 제조한 후 사용하였다.

\section{3. 청미래덩굴(Smilax china L., SC) 추출}

청미래덩굴은 8월경 전라북도 익산시 야산부근에서 채취하여 시에 위치하고 있는 대학부설 생명자원과학연구소에서 확인 동정 후 사용하였다. 채집한 청미래덩굴 전초는 깨끗이 세척 후 통풍이 잘되는 곳에서 말린 다음 일정 길이로 잘라 냉암소에 보관하여 시 료로 사용하였다. 시료추출은 시료 $82.6 \mathrm{~g}$ 을 파쇄한 다음 열수추출 을 위해 시료의 3 배 정도의 증류수와 함께 $1,000 \mathrm{~mL}$ 의 환저플라스 크에 넣고 2 시간 동안 가열하였다. 위의 과정을 5 회 반복 추출한 다 음 여과하여 $3,000 \mathrm{rpm}$ 에서 30 분 동안 원침시켰다. 원침 후 진공 농축기에서 농축감압시킨 다음 $5.1 \mathrm{~g}$ 의 시료를 얻었다. 이 때 수율 은 $6.2 \%$ 로 나타났다. 


\section{4. 세포 배양}

NIH3T3 섬유모세포의 배양은 Han 등(2006)의 방법에 따라 배 양용기에 부착된 세포를 효소해리술에 의하여 분리하였다. 분리된 세포들은 원침 후 $10 \% \mathrm{FBS}$ 가 함유된 MEM 배양액에 넣어 $1 \times 10^{5}$ cells/well의 농도로 조절한 후 96-well plate에 분주하였다. 분주 된 세포들은 72 시간 동안 $36^{\circ} \mathrm{C}, 5 \% \mathrm{CO}_{2}$ 로 조절된 항온기 내에서 배양하였다.

\section{MMC 처리}

$\mathrm{XTT}_{50}$ 값의 $\mathrm{MMC}$ 를 배양 세포에 처리하기 2시간 전에 항산화능 이 확인된 vit. E의 농도 중 연구자가 임의대로 선택한 $30 \mathrm{uM}$ 과 40 $\mathrm{uM}$ 의 농도가 포함된 배양액에서 세포를 배양한 다음 세포생존율 을 양성대조군인 $\mathrm{MMC}$ 의 처리군과 비교 조사하였다.

\section{Vit. E 처리}

Vit. E의 항산화능을 측정하기 위하여 활성산소의 일종인 20 $\mathrm{mU} / \mathrm{mL}$ glucose oxidase $(\mathrm{GO})$ 를 배양세포에 처리하기 2시간 전 에 vit. E가 각각 20 40 uM의 농도로 포함된 배양액에서 세포를 처리한 후 세포생존율을 대조군과 비교 조사하였다.

\section{7. $\mathrm{MMC}$ 에 대한 vit. E 영향}

$\mathrm{XTT}_{50}$ 값의 $\mathrm{MMC}$ 를 배양 세포에 처리하기 2시간 전에 항산화능 이 확인된 vit. $\mathrm{E}$ 의 농도 중 연구자가 임의대로 선택한 $30 \mathrm{uM}$ 과 40 $\mathrm{uM}$ 의 농도가 포함된 배양액에서 세포를 배양한 다음 세포생존율 을 양성대조군인 $\mathrm{MMC}$ 의 처리군과 비교 조사하였다.

\section{SC 추출물 처리}

$\mathrm{MMC}$ 에 대한 청미래덩굴 추출물의 영향을 조사하기 위하여 배 양 $\mathrm{NIH}_{3} 3$ 3 섬유모세포에 $\mathrm{MMCXTT} 5$ 값의 $\mathrm{MMC}$ 를 처리하기 2시 간 전에 $70 \mathrm{ug} / \mathrm{mL}$ 와 $90 \mathrm{ug} / \mathrm{mL}$ 의 추출물이 각각 포함된 배양액에 서 세포를 처리한 다음 세포생존율을 양성대조군인 $\mathrm{MMC}$ 의 처리 군과 비교 조사하였다.

\section{9. 세포생존율 분석}

세포생존율의 분석은 Borenfreund와 Puerner (1984)의 방법 에 따랐다. 즉, 배양 세포에 약제나 추출물을 농도별로 처리한 다음 실험 당일 제조한 XTT $50 \mathrm{ug} / \mathrm{mL}$ 를 well당 $100 \mathrm{ul}$ 씩 넣고 $36^{\circ} \mathrm{C}$ 로 조 절된 항온기에서 4 시간 동안 배양하였다. 배양 완료 후 dimethylsulfoxide (DMSO)를 넣어 일정시간 실온에서 정치한 다음 Variskan flash ELISA reader (Thermo Scientific Co., Vantaa,
Finland)로 $450 \mathrm{~nm}$ 에서 흡광도를 측정하였다. $\mathrm{XTT}_{50}$ 값의 산출은 회귀직선식에 의하여 산정하였다.

\section{0. 전자공여능 측정}

전자공여능(electron donating ability, $\mathrm{EDA}$ )의 측정은 Blois (1958)의 방법에 따라, 메탄올시료에 $0.3 \mathrm{mM} \mathrm{DPPH}$ 메탄올용액 $100 \mathrm{uL}$ 를 넣고 실온에서 30분간 처리하였다. 처리 완료 후 ELISA reader로 $517 \mathrm{~nm}$ 에서 흡광도를 측정하였다. $\mathrm{EDA}$ 는 시료첨가군 과 시료무첨가군 간의 차이를 시료무첨가군에 의한 백분율로 나타 냈으며, vit. E의 활성을 비교군으로 사용하기 위하여 vit. E의 항산 화능 측정에서 활성이 $50 \%$ 를 넘은 농도를 선정하여 사전실험을 한 결과 vit. $35 \mathrm{uM}$ 활성이 $50 \%$ 를 넘은 농도를 선택하여 비교 농도로 하였다.

\section{SOD-유사활성 측정}

SOD-유사활성(SOD-like activity)의 측정은 Marklund와 Marklund (1974)의 방법에 따랐다. 즉, 시료에 Tris-HCl buffer와 $10 \mathrm{mM}$ pyrogallol을 넣고 $25^{\circ} \mathrm{C}$ 에서 10 분 동안 처리하였다. 처리 후 $\mathrm{HCl}$ 로 반응시킨 다음 ELISA reader로 $420 \mathrm{~nm}$ 에서 흡광도를 측 정하였다. 또한, vit. E의 활성을 비교군으로 하였으며, 활성은 시료 첨가군과 시료무첨가군의 차이에 의한 백분율로 나타냈으며, vit. $\mathrm{E}$ 의 활성을 비교군으로 사용하기 위하여 vit. $\mathrm{E}$ 의 항산화능 측정에 서 활성이 $50 \%$ 를 넘은 농도를 선정하여 사전실험을 한 결과 활성이 $50 \%$ 를 넘은 농도를 선택하여 비교 농도로 하였다.

\section{2. 지질과산화 측정}

지질과산화능(lipid peroxidation activity, LPA)는 Kikuzaki와 Nakatani (1993)의 방법에 따라, 에탄올에 $3.9 \mathrm{~mL}$ 의 시료를 넣어 혼합한 액에 에탄올에 녹인 $2.52 \%$ linoleic acid와 $0.05 \mathrm{M} \mathrm{PBS} \mathrm{(pH}$ $7.0)$ 용액 $12.1 \mathrm{~mL}$ 를 첨가한 후 $40^{\circ} \mathrm{C}$ 에서 24 시간 동안 처리하였다. 처리 완료 후 30\% ammonium thyocyanate로 처리하고 $0.02 \mathrm{M}$ ferrous chloride $0.1 \mathrm{~mL}$ 를 가한 후 실온에서 반응시켰다. 반응 완 료 후 ELISA reader로 $500 \mathrm{~nm}$ 에서 흡광도를 측정하였다. LPA는 대조군에 대한 시료첨가군의 차이를 백분율로 표시하였다.

\section{3. 통계 처리}

자료분석은 SPSS 18.0 (SPSS Inc., Chicago. IL. USA)에 의하여 행하였으며 mean $\pm \mathrm{SD}$ 로 표시하였다. 또한, 자료에 대한 유의성 검정은 independent t-test에 의하였으며, 통계처리에 대한 유의 수준은 $p$ 값이 0.05 미만인 경우로 설정하였다. 


\section{결 과}

\section{1. $\mathrm{MMC}$ 의 독성 측정}

$\mathrm{MMC}$ 의 세포독성을 조사하기 위하여 배양 $\mathrm{NIH} 3 \mathrm{~T} 3$ 섬유모세포 에 $\mathrm{MMC}$ 가 20 40 uM 농도로 각각 포함된 배양액에서 72시간 동 안 처리한 결과, 대조군에 비해 $\mathrm{MMC}$ 의 농도가 증가할수록 세포생 존율이 유의하게 감소되었으며 $(p<0.001)$, 이 때 XTT50값은 33.7 $\mathrm{uM}$ 의 처리에서 나타났다(Table 1).

\section{Vit. E의 항산화능 측정}

세포생존율은 대조군인 $100 \%(0.226 \pm 0.05)$ 에 비하여 20 $\mathrm{mU} / \mathrm{mL} \mathrm{GO}$ 만을 처리한 경우 $35.4 \%(0.080 \pm 0.01)$ 로 나타났으 나, $20 \mathrm{uM}$ 농도의 vit. E의 처리에서는 $52.2 \%(0.118 \pm 0.03)$ 로 $\mathrm{GO}$ 만의 처리에 비하여 유의한 증가를 보였다 $(p<0.05)$. 또한, vit. $\mathrm{E}$ 를 $25 \mathrm{uM}$ 과 $30 \mathrm{uM}$ 를 처리한 결과 세포생존율이 각각 $61.5 \%$ $(0.139 \pm 0.02)$ 와 $70.4 \%(0.159 \pm 0.06)$ 로 나타났으며, $35 \mathrm{uM}$ 과 $40 \mathrm{uM}$ 의 처리에서는 각각 $81.9 \%(0.185 \pm 0.04)$ 와 $89.4 \%$ (0.202 \pm 0.07$)$ 로 나타났다. 따라서, $\mathrm{GO}$ 만의 처리에 비하여 모두 유의한 세포생존율의 증가를 보였다 $(p<0.001)$ (Table 2).

\section{MMC에 대한 vit. E의 영향}

$\mathrm{MMC}$ 의 세포독성에 산화적 손상이 관여하는지를 알아보기 위 하여 $\mathrm{XTT}_{50}$ 값의 $\mathrm{MMC} 33.7 \mathrm{uM}$ 를 배양 세포에 처리하기 2시간 전

Table 1. The cytotoxicity of MMC on cultured NIH3T3 fibroblasts by XTT assay

\begin{tabular}{|c|c|c|}
\hline Incubation & \multicolumn{2}{|c|}{ XTT assay $(450 \mathrm{~nm})$} \\
\hline Concentrations of MMC (UM) & Mean \pm SD & (\% of control) \\
\hline Control & $0.243 \pm 0.08$ & 100 \\
\hline 20 & $0.195 \pm 0.06$ & $80.2^{\star \star}$ \\
\hline 30 & $0.142 \pm 0.05$ & $58.4^{\star \star \star}$ \\
\hline 40 & $0.088 \pm 0.09$ & $36.2^{\star \star \star}$ \\
\hline $33.7\left(\mathrm{XTT}_{50}\right)$ & $0.122 \pm 0.03$ & $50.2^{\star \star \star}$ \\
\hline
\end{tabular}

Table 2. The antioxidative effect of vit. $E$ on glucose oxidase

\begin{tabular}{cccc}
\hline Incubation & \multicolumn{2}{c}{ XTT assay $(450 \mathrm{~nm})$} \\
\hline Concentrations of vit. E (uM) & Mean \pm SD & (\% of control) \\
\hline Control & $0.226 \pm 0.05$ & 100 \\
$20 \mathrm{mU} / \mathrm{ml} \mathrm{GO}$ & $0.080 \pm 0.01$ & 35.4 \\
20 & $0.118 \pm 0.03$ & $52.2^{\star}$ \\
25 & $0.139 \pm 0.02$ & $61.5^{\star \star \star}$ \\
30 & $0.159 \pm 0.06$ & $70.4^{\star \star \star}$ \\
35 & $0.185 \pm 0.04$ & $81.9^{\star \star \star}$ \\
40 & $0.202 \pm 0.07$ & $89.4^{\star \star \star}$ \\
\hline
\end{tabular}

에 항산화제인 vit. E를 $30 \mathrm{uM}$ 과 $40 \mathrm{uM}$ 의 농도로 세포에 처리하였 다. 그 결과 $\mathrm{XTT}_{50}$ 값의 $\mathrm{MMC}$ 만을 처리한 경우 세포생존율이 대조

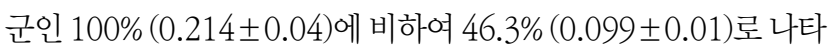
난 반면, $30 \mathrm{uM}$ 와 $40 \mathrm{uM}$ 농도의 vit. E 처리에서는 각각 $69.6 \%$

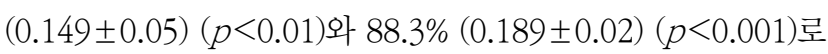
나타나 $\mathrm{MMC}$ 만의 처리에 비하여 모두 유의하게 증가하였다(Table 3).

\section{4. $\mathrm{MMC}$ 의 독성에 대한 $\mathrm{SC}$ 추출물의 영향}

$\mathrm{MMC}$ 의 세포독성에 대한 $\mathrm{SC}$ 추출물의 영향을 조사하기 위하여 $\mathrm{XTT}_{50}$ 값의 $\mathrm{MMC} 33.7 \mathrm{uM}$ 를 배양 $\mathrm{NIH} 3 \mathrm{~T} 3$ 섬유모세포에 처리하 기 전에 $70 \mathrm{ug} / \mathrm{mL}$ 와 $90 \mathrm{ug} / \mathrm{mL}$ 의 SC 추출물을 전처리한 결과, 대 조군인 $100 \%$ (0.238 \pm 0.05$)$ 에 비하여 $\mathrm{MMC}$ 만의 처리에서 세포생 존율이 $52.5 \%(0.125 \pm 0.03)$ 로 나타났으나 $70 \mathrm{ug} / \mathrm{mL} \mathrm{SC}$ 추출물 처리에서는 $62.2 \%(0.148 \pm 0.01)$ 로 나타나 $\mathrm{MMC}$ 만의 처리에 비 하여 다소 증가하였으나 통계적인 유의성은 나타나지 않았다. 그러 나, $90 \mathrm{ug} / \mathrm{mL} \mathrm{SC}$ 추출물 처리에서는 세포생존율이 $71.8 \%$ $(0.171 \pm 0.04)$ 로 나타나 $\mathrm{MMC}$ 만의 처리보다 통계적으로 유의한 증가를 나타냈다 $(p<0.01)$ (Table 4).

\section{5. $\mathrm{EDA}$ 측정}

$\mathrm{EDA}$ 를 측정하기 위하여 $70 \mathrm{ug} / \mathrm{mL}$ 와 $90 \mathrm{ug} / \mathrm{mL}$ 농도의 $\mathrm{SC}$ 추출 물 시료를 분석한 결과 $70 \mathrm{ug} / \mathrm{mL} \mathrm{SC}$ 추출물 시료의 처리에서 $\mathrm{EDA}$ 활성이 $32.6 \%$ 로 대조군에 비하여 통계적으로 유의한 증가를 나타 냈다 $(p<0.01)$. 또한, $90 \mathrm{ug} / \mathrm{mL} \mathrm{SC}$ 추출물 처리에서도 53.6\%로 나 타나 대조군에 비하여 통계적으로 유의한 증가를 보였다 $(p<0.001)$.

Table 3. The effect of vit. E on the cytotoxicity induced by MMC in cultured NIH3T3 fibroblasts

\begin{tabular}{cccc}
\hline Incubation & \multicolumn{2}{c}{ XTT assay $(450 \mathrm{~nm})$} \\
\cline { 1 - 3 } Concentrations of vit. E (uM) & Mean \pm SD & (\% of control) \\
\hline Control & $0.214 \pm 0.04$ & 100 \\
MMC (XTT 50$)$ & $0.099 \pm 0.01$ & 46.3 \\
30 & $0.149 \pm 0.05$ & $69.6^{\star \star}$ \\
40 & $0.189 \pm 0.02$ & $88.3^{\star \star *}$ \\
\hline
\end{tabular}

Table 4. The protective effect of Smilax china L. (SC) extract on MMC-induced cytotoxicity in cultured NIH3T3 fibroblasts

\begin{tabular}{cccc}
\hline \multicolumn{2}{c}{ Incubation } & \multicolumn{2}{c}{ XTT assay $(450 \mathrm{~nm})$} \\
\cline { 1 - 3 } Concent. of SC extr. (ug/mL) & Mean \pm SD & (\% of control) \\
\hline Control & $0.238 \pm 0.05$ & 100 \\
MMC (XTT 50$)$ & $0.125 \pm 0.03$ & 52.5 \\
70 & $0.148 \pm 0.01$ & 62.2 \\
90 & $0.171 \pm 0.04$ & $71.8^{\star *}$ \\
\hline
\end{tabular}


특히, $90 \mathrm{ug} / \mathrm{mL}$ 의 SC 추출물이 갖는 $\mathrm{EDA}$ 활성은 $35 \mathrm{uM}$ vit. E의 $\mathrm{EDA}$ 활성(74.2\%)보다 70\% 이상인 것으로 나타났다(Table 5).

\section{SOD-유사활성 측정}

$\mathrm{MMC}$ 에 대한 $\mathrm{SC}$ 추출물의 $\mathrm{SOD}$-유사활성에 대한 영향을 조사 하기 위하여 $70 \mathrm{ug} / \mathrm{mL}$ 와 $90 \mathrm{ug} / \mathrm{mL}$ 의 SC 추출물 시료를 분석한 결과, $70 \mathrm{ug} / \mathrm{mL} \mathrm{SC}$ 추출물 시료의 SOD-유사활성은 대조군에 비 하여 $21.4 \%$ 로 유의하게 증가하였다 $(p<0.01)$. 또한 $90 \mathrm{ug} / \mathrm{mL} \mathrm{SC}$ 추출물 시료의 처리에서도 $45.9 \%$ 로 나타나 대조군에 비하여 유의 한 활성 증가를 보였다 $(p<0.01)$. 특히, $90 \mathrm{ug} / \mathrm{mL}$ 의 추출물 시료는 비교군인 $20 \mathrm{uM}$ vit. E의 SOD-유사활성인 53.5\% ( $p<0.001)$ 에 비해 $85 \%$ 이상의 활성을 나타냈다(Table 6).

\section{LPA 측정}

$\mathrm{MMC}$ 에 대한 $\mathrm{SC}$ 추출물의 LPA에 대한 영향을 조사하기 위하여 $70 \mathrm{ug} / \mathrm{mL}$ 와 $90 \mathrm{ug} / \mathrm{mL}$ 의 SC 추출물 시료 각각을 분석한 결과 70 $\mathrm{ug} / \mathrm{mL} \mathrm{SC}$ 추출물 시료의 LPA는 대조군인 $100 \%$ 에 비하여 $83.1 \%$ 나타나 유의한 감소를 보였고 $(p<0.01), 90 \mathrm{ug} / \mathrm{mL} \mathrm{SC}$ 추출물 시료 의 처리에서는 $76.8 \%$ 로 나타나 대조군에 비하여 유의한 활성 감소 를 보였다 $(p<0.01$ ) (Table 6). 따라서 LPA는 $70 \mathrm{ug} / \mathrm{mL}$ 와 90 $\mathrm{ug} / \mathrm{mL}$ 농도에서 각각 $16.9 \%$ 와 $23.2 \%$ 로 나타나 대조군에 비하여 유의하게 증가한 것으로 나타났다 $(p<0.01)$ (Table 7).

\section{고 찰}

알러지성 접촉피부염 유발제인 $\mathrm{MMC}$ 가 배양 $\mathrm{NIH} 3 \mathrm{~T} 3$ 섬유모세 포에 미치는 독성효과를 SC 추출물이 갖는 보호효과를 확인하기 위하여 실시된 연구이다.

배양 세포인 NIH3T3 섬유모세포를 MMC를 포함한 배양액에서 72 시간동안 배양한 결과, $\mathrm{MMC}$ 는 대조군에 비하여 농도 의존적으 로 세포생존율을 유의하게 감소시켰으며 $(p<0.001)$, 이 때 $\mathrm{XTT}_{50}$ 값은 $33.7 \mathrm{uM}$ 에서 나타나 $\mathrm{MMC}$ 가 배양 $\mathrm{NIH} 3 \mathrm{~T} 3$ 섬유모세포에 세 포독성을 가지고 있음을 말해주고 있다. 또한 XTT50값이 $100 \mathrm{uM}$ 이하인 $33.7 \mathrm{uM}$ 에서 나타남으로서 Borenfreund와 Puerner

Table 5. Electron donating ability (EDA) of Smilax china L. (SC) extract determined at a wavelength of $517 \mathrm{~nm}$

\begin{tabular}{|c|c|c|}
\hline Incubation & \multicolumn{2}{|c|}{ Electron donating ability $(517 \mathrm{~nm})$} \\
\hline Experimental group & Mean \pm SD & (\% of control) \\
\hline 35 uM vit. E & $0.581 \pm 0.03$ & $74.2^{\star \star \star}$ \\
\hline $70 \mathrm{ug} / \mathrm{mL} \mathrm{SC}$ extract & $1.517 \pm 0.12$ & $32.6^{\star \star}$ \\
\hline $90 \mathrm{ug} / \mathrm{mL} \mathrm{SC}$ extract & $1.044 \pm 0.08$ & $53.6^{\star \star \star}$ \\
\hline
\end{tabular}

(1984)에 의한 독성판정기준에 의하여 고독성(highly-toxic)인 것 으로 나타났다. 이들은 독성판정기준을 XTT50값이나 $\mathrm{MTT}_{50}$ 값이 $100 \mathrm{uM}$ 이하인 경우를 고독성(highly-toxic)으로, 100 1,000 $\mathrm{uM}$ 인 경우를 중간독성(mid-toxic)으로, $1,000 ~ 2,000 \mathrm{uM}$ 인 경 우를 저독성(lower-toxic)으로, $2,000 \mathrm{uM}$ 이상인 경우를 무독성 (non-toxic)으로 각각 판정하였다. 이 같은 본 연구 결과는 Jung 등 (2008)에 의한 MMC의 배양 심장근육세포에 대한 독성보고나, $\operatorname{Kim}$ 등(2010)에 의한 MMC의 배양 인체섬유모세포에 대한 독성 보고와도 일치하였다. 이와 같이 $\mathrm{MMC}$ 가 배양 $\mathrm{NIH} 3 \mathrm{~T} 3$ 섬유모세 포에 독성을 보인 것은 $\mathrm{MMC}$ 에 의한 세포내 $\mathrm{DNA}$ 의 손상이나, 아 미노산 및 단백질합성저해와 같은 가능성도 배제할 수는 없지만 (Olson과 Massaro, 1977), 그 보다는 MMC가 메틸라디칼과 같은 자유라디칼을 생성함으로서 산화적 손상에 의하여 세포생존율의 감소를 초래하였을 가능성이 클 것으로 생각된다(Park 등, 1996). 따라서 본 연구에서는 $\mathrm{MMC}$ 에 의한 독성이 산화적 손상인지를 확 인하기 위하여 항산화의 일종인 vit. E를 적용하였다. 그러기 위해 먼저 활성산소의 일종인 GO에 대한 vit. E의 항산화능을 분석하였 다. Vit. E 20 40 uM의 농도를 처리한 결과, $20 \mathrm{uM} / \mathrm{mL}$ 의 GO만을 처리한 것보다 모두 통계적으로 유의한 세포생존율의 증가를 나타 내어 vit. E의 높은 항산화능을 확인하였다. Vit. E는 ascorbic acid 와같이 강력한 항산화제로서 식품의 불포화 지방산, 인지질, vit. A 의 산화방지 및 세포노화를 막아준다고 알려져 있다(Yamamoto 등, 1983). 따라서, MMC에 대한 vit. E의 영향을 조사하기 위하여 $\mathrm{XTT}_{50}$ 값의 $\mathrm{MMC}$ 를 배양 세포에 처리하기 전 항산화제인 vit. $\mathrm{E}$ 를 배양 세포에 처리한 결과 $\mathrm{MMC}$ 만을 처리한 경우에 비하여 $30 \mathrm{uM}$ $(p<0.01)$ 과 $40 \mathrm{uM}(p<0.001)$ 의 vit. $\mathrm{E}$ 의 처리에서는 각각 유의한

Table 6. SOD-like activity of Smilax china L. (SC) extract determined at a wavelength of $420 \mathrm{~nm}$

\begin{tabular}{ccc}
\hline \multicolumn{2}{c}{ Incubation } & \multicolumn{3}{c}{ SOD-like activity $(420 \mathrm{~nm})$} \\
\cline { 3 - 4 } \cline { 3 - 3 } Experimental group & Mean \pm SD & (\% of control) \\
\hline $20 \mathrm{uM} \mathrm{vit.} \mathrm{E}$ & $0.244 \pm 0.04$ & $53.5^{\star \star \star}$ \\
$70 \mathrm{ug} / \mathrm{mL} \mathrm{SC}$ extract & $0.193 \pm 0.05$ & $21.4^{\star \star}$ \\
$90 \mathrm{ug} / \mathrm{mL} \mathrm{SC}$ extract & $0.232 \pm 0.02$ & $45.9^{\star \star}$ \\
\hline
\end{tabular}

Table 7. lipid peroxidation activity of Smilax china L. (SC) extract determined at a wavelength of $500 \mathrm{~nm}$

\begin{tabular}{ccc}
\hline \multirow{2}{*}{ Incubation } & \multicolumn{2}{c}{ Lipid peroxidation activity $(500 \mathrm{~nm})$} \\
\cline { 3 - 3 } Concent. of SC extr. (ug/mL) & Mean \pm SD & (\% of control) \\
\hline Control & $0.237 \pm 0.02$ & 100 \\
70 & $0.197 \pm 0.07$ & $83.1^{\star \star}$ \\
90 & $0.182 \pm 0.05$ & $76.8^{\star \star}$ \\
\hline
\end{tabular}


세포생존율의 증가를 보였다. 본 실험의 결과에서 항산화제인 vit. $\mathrm{E}$ 가 $\mathrm{MMC}$ 의 독성을 방어한 것은 $\mathrm{MMC}$ 가 산화적 손상과 관련이 있 다는 것을 증명하고 있으며, 이는 Park 등(2000)에 의한 vit. E의 $\mathrm{MMC}$ 독성감소에 대한 보고나 Son 등(2013)에 의한 $\mathrm{MMC}$ 독성에 대한 vit. E의 방어효과에 대한 보고와도 일치하였다.

$\mathrm{MMC}$ 의 독성에 대한 $\mathrm{SC}$ 추출물의 영향을 조사하기 위하여 $\mathrm{XTT}_{50}$ 값의 $\mathrm{MMC}$ 를 배양 세포에 처리하기 전에 $70 \mathrm{ug} / \mathrm{mL}$ 와 90 $\mathrm{ug} / \mathrm{mL}$ 의 SC 추출물을 전 처리한 결과, $70 \mathrm{ug} / \mathrm{mL}$ 와 $90 \mathrm{ug} / \mathrm{mL} \mathrm{SC}$ 추출물 처리에서 세포생존율이 각각 $62.2 \%(0.148 \pm 0.01)$ 와 $71.8 \%(0.171 \pm 0.04)$ 로 나타났으며, 특히 $90 \mathrm{ug} / \mathrm{mL}$ 의 처리에서 는 $\mathrm{MMC}$ 만의 처리에 비하여 유의한 증가를 나타냈다 $(p<0.01)$. 본 연구 결과는 $\mathrm{SC}$ 추출물이 $\mathrm{MMC}$ 의 세포독성을 방어한 것으로서, $\mathrm{Oh}$ (2011)가 보고한 SC 추출물이 MMC와 같은 접촉피부염 유발 제인 크롬의 세포독성을 방어하였다는 연구 결과와도 상통하였다. 위에서처럼 MMC에 대한 SC 추출물의 방어효과는 Song 등(2002) 의 보고에 따라 $\mathrm{MMC}$ 에 의한 세포내 단백질합성과 관련된 내형질 세망(endoplasmic reticulum)의 기능저해나, DNA polymerase 와 같은 전구물질의 저해와 같은 현상을 방어한 이유도 있겠지만, 그 보다는 SC 추출물의 항산화작용이 $\mathrm{MMC}$ 의 산화적 손상을 방어 한 결과로 판단된다. 따라서 $\mathrm{SC}$ 추출물에 대한 항산화능의 조사를 위하여 $\mathrm{EDA}$ 를 비롯한 $\mathrm{SOD}$-유사활성 및 $\mathrm{LPA}$ 를 분석하였다. 그 결 과 $\mathrm{SC}$ 추출물은 $\mathrm{EDA}$ 를 비롯하여, $\mathrm{SOD}$-유사활성 및 $\mathrm{LPA}$ 를 나타냄 으로서 항산화 효과가 있음을 증명하였다. 특히, $90 \mathrm{ug} / \mathrm{mL}$ 추출물 시료처리에 있어서 $\mathrm{EDA}$ 와 $\mathrm{SOD}$-유사활성은 비교군인 vit. E 활성 의 $70 ~ 80 \%$ 이상의 활성을 보임으로서 vit. E와 같은 항산화능을 증명하였으며, $70 \mathrm{ug} / \mathrm{mL}$ 와 $90 \mathrm{ug} / \mathrm{mL}$ 농도에서 지질의 과산화를 감소시켰다. 이 같은 결과는 Seo 등(2012)이 SC 추출물에서 항산 화능을 보고한 연구 결과와 Pyo 등(2013)이 SC 추출물이 LDH (lactate dehydrogenase)의 활성을 억제하였다는 연구 결과와 유 사하였다. SOD-유사활성은 세포내 항산화 효소의 하나인 SOD와 같은 기능 정도를 측정하는 것으로서 이는 $\mathrm{SC}$ 추출물이 $\mathrm{SOD}$ 효소 처럼 자유라디칼의 일종인 과산화수소 $\left(\mathrm{H}_{2} \mathrm{O}_{2}\right)$ 를 물로 변환하는 유 사기능을 가지고 있음을 제시하고 있다. SC 추출물의 항산화능은 추출물 성분 중에 saponin을 비롯한 리놀렌산(linoleic acid)이나 올레인산(oleic acid)과 같은 항산화작용이 강한 성분들에 의한 것 으로 생각되며, Li 등(2007)이 SC 추출물에서 강력한 항산화 성분 의 하나인 플라보노이드(flavonoid) 물질을 분리하였다는 연구 보 고가 이를 더욱 뒷받침해 주고 있다. 특히, saponin은 인삼의 주성 분으로서 항산화능을 비롯한, 항암, 항염과 같은 유효한 약리활성 을 나타낸다고 알려져 있다(Wang 등, 2006). 그러나, SC 추출물과 같은 천연성분에 대한 항산화측면에서의 분석은 각 성분의 생리활
성은 물론, 세포내 산화적 손상과 관련된 수용체 및 신호전달계와 같은 다양한 측면에서 체계적으로 연구가 이루어져야 할 것으로 생 각된다.

\section{요 약}

알러지성 접촉피부염 유발제인 수은의 독성에 대한 청미래덩굴 (Smilax china L.) 추출물의 영향을 조사하기 위하여 배양 NIH3T3 섬유모세포에 여러 농도의 메틸수은(methylmercuric chloride, $\mathrm{MMC}$ )을 72 시간 동안 처리한 후 이들의 세포독성을 조사하였다. 또한, $\mathrm{MMC}$ 의 독성에 대한 청미래덩굴 추출물의 보호효과를 항산 화 측면에서 조사하여 다음과 같은 결론을 얻었다. $\mathrm{MMC}$ 는 농도 의 존적으로 배양 NIH3T3 섬유모세포의 세포생존율을 유의하게 감 소하였으며 XTT 50 값이 $100 \mathrm{uM}$ 이하로서 고독성(highly-toxic)인 것으로 나타났다. 또한, $\mathrm{MMC}$ 의 독성이 항산화제인 vit. E에 의하여 방어됨으로서 $\mathrm{MMC}$ 의 독성에 산화적 손상이 관여하고 있는 것으 로 나타났다. 한편, $\mathrm{MMC}$ 의 세포독성에 대한 청미래덩굴 추출물의 방어효과에 있어서 청미래덩굴 추출물은 $\mathrm{MMC}$ 에 의하여 감소된 세포생존율을 유의하게 증가시킴으로서 $\mathrm{MMC}$ 의 독성을 방어하였 다. 또한, 청미래덩굴 추출물은 전자공여능(EDA)을 비롯한 $\mathrm{SOD}$ 유사 활성(SLA) 및 지질과산화능 $(\mathrm{LPA})$ 와 같은 항산화 효과를 나타 냈다. 이상의 결과로부터 청미래덩굴과 같은 천연 성분은 산화적 손상과 관련된 염증성 피부질환의 치료를 위한 항산화제로서의 미 래 가능한 천연소재라고 생각된다.

Acknowledgements: None

Funding: None

Conflict of interest: None

\section{References}

1. Blois MS. Antioxidant determination by the use of a stable free radical. Nature. 1958,26:1199-1200.

2. Borenfreund E, Puerner JA. A simple quantitative procedure using monolayer culture for cytotoxicity assay (HTD/NR-90). J Tissue Cult Meth. 1984,9:7-9.

3. Chang JK. The wild plants for health of human body. 2rd ed. 2003, p551. Nexusbook, Seoul.

4. De-Heredia JB, Torregrosa J, Dominguez JR, Peres JA. Kinetic model for phenolic compoud oxidation by fenton's reagent. Chemosphere. 2001,45:85-90.

5. Gage JC. Mehnism for the biodegradation of organic mercury compounds: The actions of ascorbate and of soluble proteins. Toxicol App Pharmacol. 1975,32:225-238.

6. Greener Y, Kochen JA. Methylmercuric toxicity in chick 
embryo. Teratol. 1983,28:23-31.

7. Han DS, Jeon SW, Yang SJ, Choi BN, Suk SH, Hong GY, et al. The effect of poncirin on hexavalent chromoum in NIH3T3 fibroblasts in vitro. Kor J Herbol. 2006,21:101-107.

8. Jung JY, Choi YS, Lee KC. Effect of gallic acid on the cytotoxicity of mercury. J Life SCi \& Nat Res. 2008,30:88-95.

9. Kikuzaki H, Nakatani N. Antioxidant effects of some ginger constituents. J Food SCi. 1993,58:1410-1420.

10. Kim MS, Seo YM, Park ST. Antioxidant effect of kaempferol on cultured skin fibroblasts damaged by methylmercuric chloride. J Kor People Plans Environ. 2010,13:23-29.

11. Kwon PS. Antimicrobial effects of photodynamic therapy using blue light emitting diode with photofrin and radachlorin against propionibacterium acnes. Kor J Clin Lab Sci. 2015, 47:6-10.

12. Li YL, Gan GP, Zhang HZ, Wu HZ, Li CL, Huang YP, et al. A flavonoid glycoside isolated from Smilax china L. rhizome in vitro anticancer cell lines. J Ethnophamacol. 2007,113:115-124.

13. Marklund S, Marklund G. Involement of superoxide anion radical in the oxidation of pyrogallol and a convenient assay for superoxide dismutase. Eur J Biochem. 1974,47:468-474.

14. Oh YY. Protective effect of Smilax china L. extract on the cytotoxicity of chromium, environnmental pollutant. J Kor People Plans Environ. 2011,14:29-34.

15. Olson FC, Massaro EJ. Effects of methymercury on murine fetal amino acid uptake, protein synthesis and plate closure. Teratol. 1977,16:187-194.

16. Park ST, Choi MK, Lee KC, Cho KH, Suk SH, Seo EA, et al. Study on the effect of vitamin $\mathrm{E}$ on methylmercury in cultured spinal motor neurons. Korean Journal of Oriental Medical Pathology. 2000,14:107-112.
17. Park ST, Lim KT, Chung YT, Kim SU. Methylmercury-induced neurotoxicity in cerebral neuron culture is blocked by antioxidant and NMDA receptor antagonists. Neurotoxicol. 1996, 17:37-46.

18. Pyo AJ, Yoon MY, Yang HO. Cytotoxicity and protective effect of Smilax china L. extract on melanogenesis by FeSO4, an autooxidant of melanin formation. Kor $J$ Aesthet \& Cosmetol. 2013,11:77-83.

19. Rim YS, Song WS, Seo YM, Park ST, Kim SM. A study on the cytotoxic effects of several plant extracts on the cell viability and cell adhesion activity in cultured NIH3T3 fibroblast. Kor J Clin Lab Sci. 2010,42:116-124.

20. Seo HK, Lee JH, Kim HS, Lee CK, Lee SC. Antioxidant and antimicrobial activities of Smilax china L. leaf extract. Food $S C i$ Biotech. 2012,21:1723-1727.

21. Son YW, Oh SK, Choi YR, Park SH, Seo YM, Lee HJ, et al. Effects of Chelidonium majus extract on mercury-induced cytotoxicity and melanogenesis. J Invest Cosmetol. 2013,9:229-235.

22. Song HJ, Ha DH, Yoo KS, Park ST, Lee KC, Seo BI. Effect of Sophorae radix on methylmercury-induced myotoxicity in cultured myocardial cells. Kor J Herbol. 2002,17:119-124.

23. Tsubaki T, Takahashi H. Recent advances in Minamata disease studies. 2rd ed. 1986, p142-146. Kodansa, Tokyo.

24. Yamamoto M, Scima T, Uozumi T, Yamada K, Kawasaki T. A possible role of lipid peroxidation in celllular damage caused by cerebral ischemia and protective effect of alpa-tocopherol administration. Stroke. 1983,14:977-982.

25. Wang CZ, Wu JA, McEntee E, Yuan CS. Saponins composition in American ginseng leaf and berry assayed by high-performance liquid chromatography. J Argic Food Chemetol. 2006,54:22612266. 